\title{
Evaluation of learning communities: principles to guide practice
}

\author{
Miriam Ossevoort, Jan Riezebos
}

Faculty of Economics and Business, University of Groningen, The Netherlands.

\begin{abstract}
The aim of this paper is to evaluate the implementation of extra-curricular learning communities (LCs) that are open for all students at the faculty of Economics and Business. The LCs were developed using established guiding principles that included the choice of the theme, the educational concept, and the scheduling. During 5 semesters, 37 LCs, of which 17 unique LCs, were executed. According to the guiding priniciples, the themes extended beyond themes of regular courses and attracted both BSc and MSc students from different degree programs. Furthermore, the theme enhanced students' professional preparation and employability. The combination of insight from practice with theory was positively evaluated. Despite the guiding principle, half of the LCs were topic-based instead of project-based. Since students strongly agreed that all LCs were a good learning experience, we have modified this guiding principle. Most points of improvement given by the students concerned the scheduling. They missed the structure they have during regular courses. Especially in the beginning of the LC they want to have more meetings to get a head start. Overall, great commitment of lecturers as well as students led to a successful realisation of these multidisciplinary, extra-curricular and multi-level LCs.
\end{abstract}

Keywords: Learning Communities; Higher Education; Student-centered Learning; Extra-curricular Activity; Employability 


\section{Introduction}

The increased number of students in higher education institutions leads to large classes with less contact between the lecturers and the students. Furthermore, students can feel lost and anonymous. To create a sense of belonging, the learning community (LC) as educational format receives a lot of attention by higher education institutions. Though many forms and definitions of LCs exist, they do have some common academic and social features. A LC should be a joint enterprise that binds members together into a social entity (Wenger, 2000). Most LCs incorporate active and collaborative learning activities. Active learning means student-centered learning. Students need to actively construct and assimilate knowledge. Herewith the focus of instruction shifts from the lecturer to the students. Collaborative learning implies a social emphasis on learning. This peer learning and interaction allow the development of complex ways of thinking so that students learn at a deeper level and move to higher levels of intellectual and psychological development (Bransford et al., 2000; Lave \& Wenger, 1994). This is based on Vygotsky's (1978) social constructive theory. By interaction with peers from different cultural and disciplinary backgrounds a disequilibrium is introduced that sets the stage for students to get in contact with different perspectives. This disequilibrium can also be threatening and confronting (Hoban, 1999), but this can be addressed through mutuality, meaning students of the LC are in a similar position and have a common goal (Lee \& Boud, 2003).

The aim of this paper is to evaluate the implementation of extra-curricular LCs that are open for all BSc and MSc students at the faculty of Economics and Business. The LCs were developed using established guiding principles (see section 2). The questions we want to answer are:

1. Which guiding principles are actually implemented in the LCs?

2. How do students evaluate the LCs?

In section 3, the description of the data collection and analysis is given. The characteristics of the implemented LC and the participating students is given in section 4. This section also includes the results of the students' evaluation. In section 5, the discrepancy between the guiding principles and the characteristics of the implemented LCs will be discussed.

\section{Implementation of learning communities: guiding principles on paper}

\subsection{Context}

The LCs are implemented at the faculty of Economics and Business (FEB) of the University of Groningen, the Netherlands. FEB's educational portfolio consists of four broad bachelor's degree programs, twelve specialised master's degree programs, and one research master program. Yearly, the total number of students is around 6700. The LCs are 
part of the activities of the department FEB Careers Services to strengthen students' professional preparation and increase graduates' employability.

\subsection{Guiding principles}

To create additional learning activities to strengthen students' professional preparation and increase graduates' employability, FEB has developed a concept for extra-curricular, multilevel and multi-discipline LCs. Extra-curricular means that students do not receive credits that contribute to their degree program, but receive a certificate for participation. As such, students from BSc as well as MSc level and multi-disciplines can enter one LC. This situation is not facilitated within regular courses of a degree program. The LCs at FEB are student-type learning communities, specially designed for targeted groups with a similar academic interest (Lenning and Ebbers, 1999). The guiding principles include the choice of the theme, the educational concept, and the scheduling. The theme for such a LC should attract both BSc and MSc students from different degree programs, thereby using their own and each other's competences. In addition, the theme should enhance and strengthen the societal and employability awareness experience using real life challenges as the core activity of the LC. Furthermore, the theme should extend beyond themes of regular courses. This is possible, since the LC is extra-curricular. This gives the lecturer the opportunity to address any topic of interest that cannot be addressed in regular courses of a degree program.

The educational concept of the LC is project-based learning, a popular approach in business education (Smith \& Gibson, 2016). To participate in a LC, students need to hand in a motivation letter. The lecturer will initiate the LC by inviting students and introducing them to the problem or assignment and gives them directions. Preferably, the project is commissioned by a client from a company, resulting in an authentic learning experience. From then on, students are in charge of the project under supervision of the lecturer. Depending on the project, students will formulate the problem, gather knowledge through e.g. literature research, interviewing, company visit, gather and analyse data, and draw a conclusion or draw up an advice. The lecturer assists the students by giving lectures on certain topics and workshops on certain skills. At the end, students will present their deliverable to the lecturer and the client, if applicable.

The LC is scheduled during a semester with preferably once every two weeks a meeting of 2 hours. Students' time investments depend on their own ambitions.

\section{Methodology}

This papers presents the results of the implementation of LCs organized during 5 semesters in the academic year, 2016-2017 (s1, s2), 2017-2018 (s3, s4), and 2018-2019 (s5). Of each 
LC, several characteristics are analyzed based on the LC's description, such as the educational format (topic-based or project-based), topics offered, skills offered, and link with the professional field (guest lecture, company visit, company project). The skills are categorized in three main areas of $21^{\text {st }}$ century skills according to Trilling and Fadel (2009): learning and innovation skills (e.g., critical thinking, communication, problem solving), digital literacy skills (e.g., media literacy, ICT technology), and career and life skills (e.g., flexibility, cross-cultural interaction, adaptivity, and self-direction).

In addition, the characteristics (gender, nationality, level of education (bachelor or master), discipline) of the participants are analyzed. Herewith we are able to describe if the group of participants within a LC is diverse in gender, nationality, level of education (BSc/MSc), and/or discipline. The LCs were evaluated by the students by filling out a questionnaire consisting of 5-point Likert scale items and open-ended questions on paper during the last meeting of the LC after receiving their certificate. The items dealt among others with students' perception on working with students of different educational levels and different disciplines, and on acquiring different skills, such as employability skills. 
Table 1. The topic and number of implemented LCs per semester.

\begin{tabular}{|c|c|c|c|c|c|c|c|}
\hline & & S1 & $\mathbf{S 2}$ & $\mathbf{S 3}$ & S4 & S5 & $\begin{array}{l}\text { Total number } \\
\text { of participants }\end{array}$ \\
\hline 1 & Mergers \& Acquisitions in SME's & $\mathrm{x}$ & $\mathrm{x}$ & & $\mathrm{x}$ & & 43 \\
\hline 2 & Big Data & $\mathrm{x}$ & & & $\mathrm{x}$ & & 22 \\
\hline 3 & Programming (Python) & $\mathrm{x}$ & $\mathrm{x}$ & $\mathrm{x}$ & $\mathrm{x}$ & $\mathrm{x}$ & 95 \\
\hline 4 & Integrated Reporting in SME's & & & $\mathrm{x}$ & $\mathrm{x}$ & $\mathrm{x}$ & 9 \\
\hline 5 & Strategy: getting real about options & & $\mathrm{x}$ & & $\mathrm{x}$ & & 12 \\
\hline 6 & $\begin{array}{l}\text { Social Impact Analysis of Global } \\
\text { Investments }\end{array}$ & $\mathrm{x}$ & & & & & 5 \\
\hline 7 & $\begin{array}{l}\text { New Business Developments in } \\
\text { Africa }\end{array}$ & & $\mathrm{x}$ & $\mathrm{x}$ & $\mathrm{x}$ & $\mathrm{x}$ & 43 \\
\hline 8 & Sustainable City Logistics & & & $\mathrm{x}$ & $\mathrm{x}$ & $\mathrm{x}$ & 23 \\
\hline 9 & Women in Business & & & $\mathrm{x}$ & & $\mathrm{x}$ & 21 \\
\hline 10 & $\begin{array}{l}\text { Working with Agile Project } \\
\text { Management Tools }\end{array}$ & & & & $\mathrm{x}$ & & 14 \\
\hline 11 & Programming $(\mathrm{R})$ & & & & $\mathrm{x}$ & & 29 \\
\hline 12 & Economic Policy Research in Practice & & & & $\mathrm{x}$ & & 23 \\
\hline 13 & Block Chain & & & & & $\mathrm{x}$ & 10 \\
\hline 14 & Energy Transition & & & & & $\mathrm{x}$ & 5 \\
\hline 15 & $\begin{array}{l}\text { Insights in the International North: } \\
\text { Digital Mapping }\end{array}$ & & & & & $\mathrm{x}$ & 9 \\
\hline 16 & International Negotiations & & & & & $\mathrm{x}$ & 7 \\
\hline 17 & Lean Six Sigma & & & & & $\mathrm{x}$ & 17 \\
\hline & Total & 4 & 4 & 5 & 10 & 10 & 387 \\
\hline
\end{tabular}

\section{Implementation of learning communities: practice}

\subsection{Characteristics of learning communities}

In total, 37 LCs were organized, but 33 LCs were executed (Table 1). Eight LCs were held more than once, resulting in 17 unique LCs with a diversity of subjects (Table 1). Three LCs were not held due to lack of applicants. Another LC was a field trip to Silicon Valley, 
which was canceled for lack of sponsoring (costs). Especially at the start of the project, the LC was initiated by the lecturer based on his/her own interest and expertise. Later on, several LCs were initiated by the project coordinator and an expert of the field on request by students, such as Lean Six Sigma, Economic Policy Research, and Working with Agile Project Management Tools.

The educational format of the LCs was either topic-based $(n=8)$ or project-based $(n=8)$, or both topic- and project-based $(\mathrm{n}=1)$ (Table 2). In almost all LCs, there was contact with the professional field, for instance by company visits, interviews or projects derived from companies. The topic- or project-based LCs were held during one semester and students all worked on one project together. The topic- and project based LC, programming (Python), was held continuously. Students could enter every semester at the level of a novice (learning programming through instruction), a beginner, or an expert (both working on projects). The skills written in the description of the LCs were categorized. Almost all LCs offer learning and innovation skills. Seven LCs offer digital literacy skills and 13 LCs offer career and life skills (Table 2).

\subsection{Characteristics of the participating students}

All learning communities, except for one, consisted of students of different disciplines. This one LC, the first LC on Big Data, only consisted of MSc Marketing students. This was probably caused by the fact that the lecturer promoted the LC during a regular course of the MSc Marketing degree program. Two other LCs (Social Impact Analysis of Global Investments and Working with Agile Project Man. Tools) also consisted only of MSc students. All LCs consisted of students with different nationalities. Most of the LCs showed gender diversity, except for Women in Business (twice, only female students), M\&A in SMEs (S2, only male students), and Integrated Reporting (S3, only male students).

\subsection{Students' evaluation}

Overall, students strongly agreed that the LCs as a whole was a good learning experience for them (mean score 4.5). Especially, the combination of insight from practice using cases of companies with theory was positively evaluated. The theme kept the students motivated to continue to participate in the LC.

The educational format and the guidance by the lecturers is experienced as helpful and pleasant. One student (LC Big data) stated that 'the good thing is that they didn't helped us too much. This way we were forced to discover our own ways to solve problems'. 
Table 2. The educational format of and the skills offered by the LCs.

\begin{tabular}{|c|c|c|c|c|c|c|}
\hline & \multirow[b]{2}{*}{ LCs topics } & \multicolumn{2}{|c|}{$\begin{array}{c}\text { Educational } \\
\text { format, based on }\end{array}$} & \multicolumn{3}{|c|}{ 21st Century Skills offered } \\
\hline & & topic & project & $\begin{array}{l}\text { Learning } \\
\text { and } \\
\text { innovation }\end{array}$ & $\begin{array}{c}\text { Digital } \\
\text { Literacy }\end{array}$ & $\begin{array}{l}\text { Career } \\
\text { and life }\end{array}$ \\
\hline 1 & $\begin{array}{l}\text { Mergers \& Acquisitions in } \\
\text { SME's }\end{array}$ & $\sqrt{ }$ & - & $\sqrt{ }$ & $\sqrt{ }$ & $\sqrt{ }$ \\
\hline 2 & Big Data & - & $\sqrt{ }$ & $\sqrt{ }$ & $\sqrt{ }$ & $\sqrt{ }$ \\
\hline 3 & Programming (Python) & $\sqrt{ }$ & $\sqrt{ }$ & $\sqrt{ }$ & $\sqrt{ }$ & $\sqrt{ }$ \\
\hline 4 & $\begin{array}{l}\text { Integrated Reporting in } \\
\text { SME's }\end{array}$ & $\sqrt{ }$ & - & $\sqrt{ }$ & - & $\sqrt{ }$ \\
\hline 5 & $\begin{array}{l}\text { Strategy: getting real about } \\
\text { options }\end{array}$ & - & $\sqrt{ }$ & $\sqrt{ }$ & - & $\sqrt{ }$ \\
\hline 6 & $\begin{array}{l}\text { Social Impact Analysis of } \\
\text { Global Investments }\end{array}$ & - & $\sqrt{ }$ & $\sqrt{ }$ & - & $\sqrt{ }$ \\
\hline 7 & $\begin{array}{l}\text { New Business Developments } \\
\text { in Africa }\end{array}$ & - & $\sqrt{ }$ & $\sqrt{ }$ & $\sqrt{ }$ & $\sqrt{ }$ \\
\hline 8 & Sustainable City Logistics & - & $\sqrt{ }$ & $\sqrt{ }$ & $\sqrt{ }$ & $\sqrt{ }$ \\
\hline 9 & Women in Business & $\sqrt{ }$ & - & $\sqrt{ }$ & - & $\sqrt{ }$ \\
\hline 10 & $\begin{array}{l}\text { Working with Agile Project } \\
\text { Management Tools }\end{array}$ & $\sqrt{ }$ & - & $\sqrt{ }$ & - & $\sqrt{ }$ \\
\hline 11 & Programming (R) & $\sqrt{ }$ & - & - & $\sqrt{ }$ & - \\
\hline 12 & $\begin{array}{l}\text { Economic Policy Research in } \\
\text { Practice }\end{array}$ & - & $\sqrt{ }$ & $\sqrt{ }$ & - & $\sqrt{ }$ \\
\hline 13 & Block Chain & $\sqrt{ }$ & - & $\sqrt{ }$ & $\sqrt{ }$ & - \\
\hline 14 & Energy Transition & - & $\sqrt{ }$ & $\sqrt{ }$ & - & - \\
\hline 15 & $\begin{array}{l}\text { Insights in the International } \\
\text { North: Digital Mapping }\end{array}$ & - & $\sqrt{ }$ & $\sqrt{ }$ & - & $\sqrt{ }$ \\
\hline 16 & International Negotiations & $\sqrt{ }$ & - & $\sqrt{ }$ & - & $\sqrt{ }$ \\
\hline 17 & Lean Six Sigma & $\sqrt{ }$ & - & $\sqrt{ }$ & - & - \\
\hline
\end{tabular}


Students enjoyed working with students with a different educational level (mean score 4.2) and background (mean score 4.4). Some remarks students made are: 'I think that different levels add their own ideas and way of thinking to the LC' (LC M\&A in SMEs), 'It is interesting they [students of different disciplines] have different ideas on the same business problem' (LC Strategy), and 'People were sharing their knowledge in their fields during the discussion' (LC M\&A in SME's). Most points of improvement giving by the students concerned the scheduling. They missed the structure they have during regular courses. Especially in the beginning of the LC they want to have more meetings to get a head start.

\section{Discussion and Conclusion}

The aim of this paper is to evaluate the implementation of extra-curricular, multi-level and multi-disciplinary LCs that are open for all students at the faculty of Economics and Business. The LCs were developed using established guiding principles including the choice of the theme, the educational concept, and the scheduling. The questions we want to answer are which guiding principles actually are implemented in the LCs and how do students evaluate these guiding principles in the LCs.

There was a great variety in themes, which attracted both BSc and MSc students from different degree programs. The themes of the executed LCs were all beyond the regular curricula. The LCs that were offered but did not continue due to lack of students did have a theme that is part of the regular curriculum, namely entrepreneurship, sustainability, and ethics. Hence, students were probably not interested to follow these LCs. Furthermore, most LCs offered career and life skills. If no contact with the professional field was included, students asked for it. So, in the future we need to stress that contact with the professional field and a theme not covered in the regular curriculum is a necessity.

Despite the guiding principle, half of the LCs were project-based. The other LCs were organized on basis of learning a topic or skill, such as Programming (R), Lean Six Sigma, and Block chain. These LCs also did not offer career and life skills. Nevertheless, students appreciate these LCs and were very motivated to learn the knowledge and skills offered. So, in the future this format should be allowed with the requirement that the LC should offer knowledge and skills that strengthen students' professional preparation and increase graduates' employability.

Since the most important points of improvement of the students was to increase the contact hours at the beginning of the LCs, the guiding principle during the 5 semesters changed from meetings every 2 weeks to weekly meetings in the beginning followed by less meetings towards the end of the LC. 
In conclusion, we have evaluated the implementation of extra-curricular, multi-disciplinary and multi-level learning communities (LCs). The results lets us conclude that according to the guiding principles, a variety in themes were implemented. In addition, in contrast to the guiding principles also a variety of educational formats and schedules were implemented. However, students' positive experiences make clear this should be allowed in the future. A key issue to reinforce in the future is to emphasize that the career and life skills should be part of each LC and the contact with the professional field is a necessity. In general, these guiding principles can be used to create extra-curricular, multi-disciplinary and multi-level LCs at any higher education institution. Overall, the great commitment of lecturers as well as students led to a successful realization of these multi-disciplinary, extra-curricular and multi-level LCs.

\section{Acknowledgements}

Authors thank Marjan van Ittersum-Leegte for providing information for writing this manuscript.

\section{References}

Bransford, J. D., Brown, A. L., \& Cocking, P. R. (eds) (2000). How People Learn: Brain, Mind, Experience, and School. Washington: National Research Council/National Academy Press.

Hoban, G. (1999) The role of community in action learning: A Deweyian perspective on sharing experiences. In Learning communities in Education: Issues, strategies and contexts, ed. J. Retallick, B. Cocklin, and K. Coombe. London: Routledge.

Lave, J., \& Wenger, E. (1994) Situated learning: legititmate peripheral participation. Cambridge: Cambridge University Press.

Lee, A; \& Boud, D. (2003). Writing groups, change and academic identity: Research development as local practice. Studies in Higher Education, 28(2), 187-200. doi: 10.1080/0307507032000058109.

Lenning, O., \& Ebbers, L. (1999). The powerful potential of learning communities: Improving education for the future. ASHE-ERIC Higher Education Report, 26(6).

Smith, P. P., \& Gibson, L.A. (2016). Finding the why: personalizing learning in higher education. New directions for teaching and learning, 145, 41-46. doi: 10.1002/t1.20173.

Trilling, B., \& Fadel, C. (2009). 21st Century skills: learning for life in our times. San Francisco: John Wiley \& Sons.

Vygotsky, L. S. (1987). Thinking and speech. In R. W. Rieber \& A. S. Carton (eds.), The collected works of L. S. Vygotsky. Vol. 1. Problems of general psychology (pp. 39285). New York: Plenum.

Wenger, E. (2000). Communities of practice and social learning systems. Organization, 7, 225-245. doi: 10.1177/135050840072002. 